\title{
DESIGN AND DEVELOPMENT OF CERAMIC CANDLE FILTER FROM OHIYA CLAY
}

\author{
Ibeh Matthew Imagwuike \\ Department of Mechanical Engineering, \\ Michael Okpara University of Agriculture, Umudike, Nigeria; \\ matthewibeh@gmail.com \\ *Nwadinobi Princewill Chibundo \\ Department of Mechanical Engineering, \\ Abia State University, Uturu, Abia State, Nigeria; \\ chibundop@gmail.com \\ DOI: $10.31364 /$ SCIRJ/v9.i10.2021.P1021894 \\ http://dx.doi.org/10.31364/SCIRJ/v9.i10.2021.P1021894
}

\begin{abstract}
This study investigates the design and development of Ceramic candle filters from Ohiya clay and their performances to improve the physical quality of drinking water. The ceramic candle filters were produced from Ohiya clay, feldspar, silica and hardwood sawdust mix. The optimal mixing ratio for clay, feldspar and silica in wt \% was obtained as 36:30:12 at a firing temperature of 900oC. However, due to the low porosity value obtained, $22 \mathrm{wt}$. \% hardwood dust was added which was the most efficient and ideal mix. The water pH, total dissolved solids (TDS) and total suspended solids (TSS) of water sample after filtration were analyzed. In relation with filtration
\end{abstract}

\section{INTRODUCTION}

Many people, particularly in underdeveloped countries, suffer from a lack of access to safe drinking water and are at risk of contracting waterborne infections from contaminated water (Enyew and Tesfaye, 2017). Surface water bodies like rivers, lakes, unprotected springs, and ponds provide the majority of these waters. The majority of these polluted surface waters are caused by people using them for animal watering, laundry, bathing, and other domestic purposes, rendering them unfit for human consumption. Some low-scale water treatment procedures, such as boiling, chlorination, solar water disinfection, natural coagulation, and bio-sand filtration, are used to remove waterborne disease-causing bacteria with varying degrees of efficacy and downsides in order to improve human water usage (Palmateer et al, 1999; Yang and Shang, 2004; Enyew and Tesfaye, 2017).

Ceramic water filtration, which is the process of passing water through a porous ceramic material, is a promising technique to efficiency, $\mathbf{7 8 . 3 \%}$ and $\mathbf{7 9 . 2 \%}$ for the total dissolved solid (TDS) and total suspended solid (TSS) respectively were obtained. The water $\mathbf{p H}$ level obtained after filtration was 7.10. The results reveal the ability of the ceramic candle filters made from Ohiya clay as a viable water treatment alternative.

Keywords: Ohiya Clay, ceramics candle water filter, porosity, filtration efficiency

lessen the burden of water-borne diseases, according to Agbo et al. (2015). It is cost-effective and produced from locally sourced materials. Other advantages of locally produced ceramic filters are portability, light weight, cost, and low maintenance. Unlike chemical or thermal disinfection, ceramic filters do not significantly affect water temperature or taste, nor do they reduce turbidity (Clasen et al, 2004; Martins and Nelson, 2011). Even while manufacturers often recommend that the filter element be replaced every 1-2 years (Campbell, 2005), they have the ability to have a long usable life of five years or more with adequate care and maintenance. Ceramic filters are versatile in design and can be molded into a variety of shapes, including flower vases, pots, discs, and candles (Lamichhane and Kansakar, 2013). Porous ceramic as a filter material has a long history and continues to play an important role in filtering today (Heidenreich and Wolters, 2004). Furthermore, the Centers for Disease Control and Prevention (CDC) of the United States Agency for International Development (USAID), CDC (2011) acknowledged that locally 
manufactured ceramic filters are used to treat household water and that they are the most widely used traditional household water treatment systems (HWTS) around the world. For all applications involving high temperatures and/or chemically hostile environments, ceramic filter elements are often used.

Clay is clearly the most important component in the creation of ceramic filters. As a result, apparent density, porosity, shrinkage, compressive strength, refractoriness, water absorption coefficient, and modulus of rupture are all physical qualities of clay that are required for ceramic applications (Jan et al., 2015). The crystalline structure of clay determines its physical qualities, as well as the ceramic properties of clay products, such as mechanical strength, hardness, toughness, dielectric constant, and optical properties. The mechanical, optical, thermal, electrical, and magnetic properties of ceramic materials are all influenced by the crystallinity or microstructure of the clay. The use of ceramic filter elements over metal filter elements is supported by the ceramic material's chemical inertness when cleaning solutions are used and its long service life (Heidenreich, 2011). Ceramic filter elements have also been effectively employed as coalesces for separating aerosols from gas flows at higher gas temperatures or with more aggressive gas media, catalyst recycling in chemical manufacturing processes, digester gas filtration, and compressed air filtration. Ceramic filter elements are employed in a variety of liquid filtration processes, including the filtration of a wide range of chemicals, as well as process water, wastewater, and water. Ceramic filter components are also utilized to remove and recycle catalysts from the manufacturing of liquid chemical products (Heidenreich, 2011). The capacity to clean and chemical resistance are the most important parameters for selecting ceramic filter elements.

As a result, the goal of this project is to design and produce candle ceramic water filters using an ideal blend of Ohiya clay, feldspar, silica, and sawdust. In addition, the designed filter's performance effectiveness on performance parameters of water $\mathrm{pH}$, total dissolved solids (TDS), and total suspended solids (TSS) of the sample after filtration was investigated.

\section{MATERIALS AND METHODS}

According to Cao et al. (2007) and Agbo et al. (2015), ceramic water candle filter formulations typically contain about $80 \%$ clayey body and are expected to have performance parameters of cold compressive strength, linear shrinkage, water absorption rate, and apparent porosity in the ranges of $\geq 10 \mathrm{MPa}, \leq 5 \%, \geq 10 \%$, and $\geq 20 \%$, respectively. As a result, individual performance metrics for compressive strength, linear shrinkage, water absorption rate, and apparent porosity were determined to be 98 percent, 99 percent, 91 percent, and 96 percent, respectively, using empirical models developed by Ibeh (2019). At a firing temperature of $900^{\circ} \mathrm{C}$, the best mixture ratio for clay, feldspar, and silica in weight percent was $36: 30: 12$. Due to the low porosity value obtained, 22 wt. percent hardwood dust was added to the clayey body (as a burn-off agent) during the formulation of the ceramic water candle filter to raise the porosity value.

\section{Production of Ceramic Water Candle Filter from Ohiya Clay}

The mixture of Ohiya clay, feldspar, silica, and sawdust was combined with water until it formed a continuous homogeneous colloidal slurry, which was sieved through a $200 \mu \mathrm{m}$ sieve to produce a silt of mixture. To remove the surplus water, the silt was put into a plaster of Paris mold and air dried. Prior to compounding with the optimal mix generated from the optimization plot, the dried silt mixture was pulverized with a hammer mill. Before slip casting, the mixture was mixed in water and deflocculated using $5 \mathrm{mls}$ of sodium silicate. After securing the candle plaster of Paris mold with a rubber band, the slip was swirled with an electrical stirrer to ensure uniformity of the components in the slip. The slip was then poured into plaster of Paris molds, with the excess water absorbed by the mold while the casting solidified.

The ceramic water candle filter was air dried for 5 days before being fired in a gas kiln at $900^{\circ} \mathrm{C}$ to remove excess moisture content from the slip. The candles were then fettled to remove the outline of the mould that appeared on the candle before being fired in a gas kiln at $150^{\circ} \mathrm{C}$ to remove excess moisture content from the slip.

fettled to remove the outline of the mould that appeared on the candle followed by firing in a gas kiln at 9000 C. Samples of the 
ceramic water candle filter obtained were subjected to experimental evaluation which includes test of water $\mathrm{pH}$, total

\section{RESULTS AND DISCUSSIONS}

Mixture of Ohiya clay, feldspar, silica and hardwood sawdust was applied in the production of ceramic filter shown in Figure 1. Hard wood sawdust is preferred to soft wood sawdust because according to (Mcallister, 2005); hardwood sawdust will not bloat as much as sawdust from soft woods resulting in more uniform pores and fewer defects in the filter. The ceramic water candle filter was fired at $900 \mathrm{oC}$ and this is justified by the works of Cao et al. (2007) and Agbo et al. (2015).

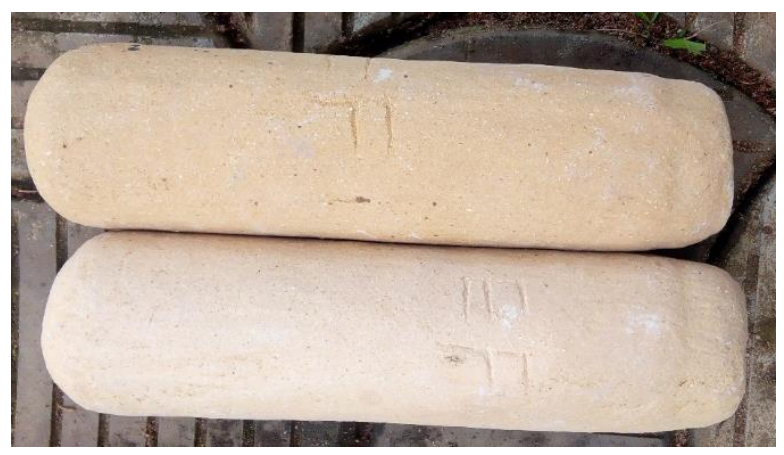

Figure 1: Ceramic water candle Filter

Figure 2 showed the water filteration setup using produced ceramic candle filter. This include a water filtering component, a lidded container to hold clean water and a valve for easy access of water.

Evaluation of the suitability of Ohiya clay in ceramic water candle filter production was carried out using the water $\mathrm{pH}$, total dissolved solid (TDS) and total suspended solid (TSS) of the filtered water as evaluation parameters as shown in table 1 and the water source used in this evaluation is the Umudike river. dissolved solids (TDS) and total suspended solids (TSS) of water sample after filtration.

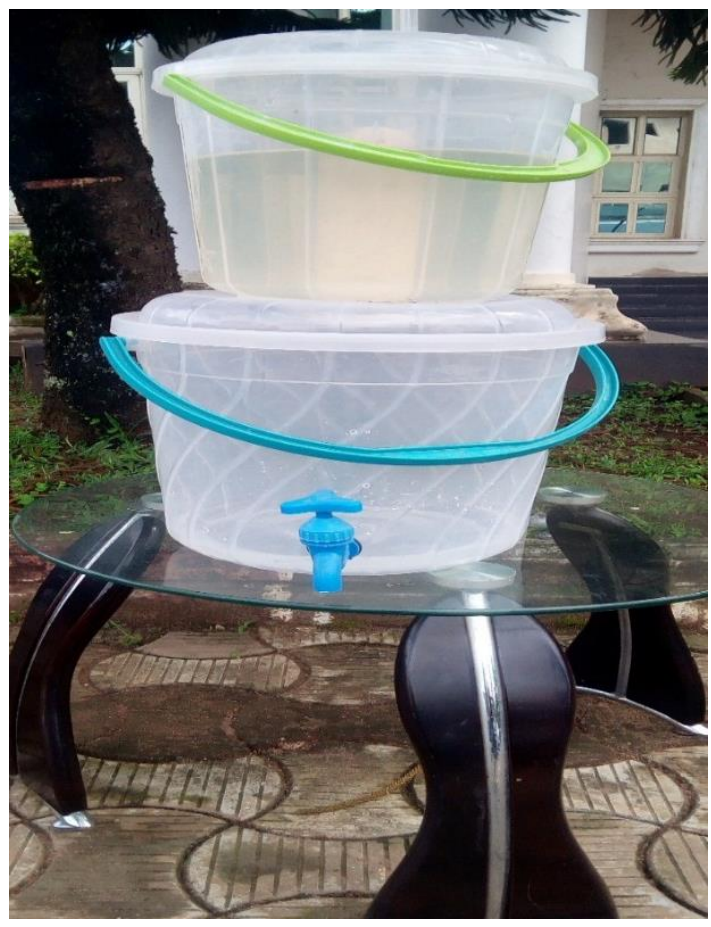

Figure 2: Water Filteration setup using produced ceramic candle filter

Table 1: Ceramic water candle filter Performance test

\begin{tabular}{clll}
\hline S/N & $\begin{array}{l}\text { Evaluation } \\
\text { Parameter }\end{array}$ & $\begin{array}{l}\text { Before } \\
\text { Filtration }\end{array}$ & $\begin{array}{l}\text { After } \\
\text { Filtration }\end{array}$ \\
\hline 1. & Water $\mathrm{pH}$ level & 6.50 & 7.10 \\
2. & TDS (mg/L) & 60 & 13 \\
3. & TSS (mg/L) & 1.20 & 0.25 \\
\hline Filtration Efficiency & \multicolumn{2}{c}{ TDS $=78.3 \%$} \\
$=$ & Before - After & & TSS $=79.2 \%$ \\
& Before filtration & & \\
$\times \mathbf{1 0 0}$ & &
\end{tabular}

The experimental result obtained and shown in table 1 for the performance test of the ceramic water candle filter indicates a filtration efficiency of $78.3 \%$ and $79.2 \%$ for the total dissolved solid (TDS) and total suspended solid (TSS) respectively. The water $\mathrm{pH}$ level after filtration (7.10) is within the recommended standard by the world health Organization (WHO) for pure water (WHO 2004; Agbo et al., 2015). It was also noted that the absorption water rate of the filter decreases with increased sintering temperature above $900^{\circ} \mathrm{C}$. 
The actual water absorption rate increased to $25.15 \%$ and that of apparent porosity increased from $14 \%$ to $30.40 \%$. This in turn increased the filtration efficiency of the produced ceramic water candle filter. The use of Ohiya clay in ceramic filter production can also aid in reduction of water borne diseases in households. As stated by USAID (2008), about 60-70\% reduction in diarrheal disease incidence has been documented in use of quality ceramic filters. Quality ceramic filters such as those produced from Ohiya clay deposits can effectively remove most of the larger protozoal and bacterial organisms because the clay contains significant mineralogical composition required for filter applications as recommended by USAID (2008).

\section{CONCLUSION}

This study used locally obtained materials to design and produce ceramic candle water filtration as a cost-effective water treatment device. Ceramic candle filters made from a mixture of Ohiya clay, feldspar, silica, and hardwood sawdust all performed better in this investigation. This was in connection to the total dissolved solid (TDS) and total suspended solid (TSS) filtering effectiveness of 78.3 percent and 79.2 percent, respectively. After filtration, the $\mathrm{pH}$ of the water was found to be 7.10. As a result, making ceramic candle water filters with this clay sample mix will be a significant step forward in the development of a low-cost, effective water treatment technique.

\section{REFERENCES}

[1] Enyew Amare Zereffa, Tesfaye Betela Bekalo, 2017. Clay Ceramic Filter for Water Treatment, Materials Science and Applied Chemistry, vol. 34, pp. 69-74 doi: 10.1515/msac-20170011

[2] Palmateer G., D. Manz, A. Jurkovic, R. McInnis, S. Unger, K. K. Kwan and B. J. Dutka, 1999. "Toxicant and parasite challenge of Manz Intermittent Slow SandFilter," Environmental Toxicology, vol. 14, no. 2, pp. 217-225.

[3] Yang X. and C. Shang, "Chlorination Byproduct Formation in the Presence of Humic Acid, Model Nitrogenous Organic
Compounds, Ammonia, and Bromide," 2004. Environmental Science \& Technology, vol. 38, no. 19, pp. 4995-5001.

[4] Agbo S. C., E. U, Ekpunobi, C. C. Onu and K. G. Akpomie 2015. Development of ceramic filter candle from nsu (kaolinite clay) for household water treatment. International journal of multidisciplinary sciences and engineering, vol. 6, no. 10, october 2015. Pp. 18 -23.

[5] Clasen T.F., J. Brown, S. Collin , O. Suntura, S. Cairncross ,Reducing diarrhea through the use of household-based ceramic water filters: a randomized, controlled trial in rural Bolivia, Am. J. Trop. Med. Hyg. 73 (4) (2004) 790-795 .

[6] Martins O.I. , A.E. Nelson , Evaluation of a ceramic pot made from local materials as water purification systems, Int. J. Sci. Adv. Tech. 1 (6) (2011) 225-233 .

[7] Campbell E., Study of Life Span of Ceramic Filter Colloidal Silver Pot Shaped Model, 2005. Agua Solutions, Managua Nicaragua,

[8] Lamichhane S. and B. R. Kansakar, "Comparison of the Performance of Ceramic Filters in Drinking Water Treatment," 2013. International Journal of Engineering and Innovative Technology, vol. 3, no. 1, pp. 481-485.

[9] Heidenreich S. and C. Wolters (2004), Porous ceramic and its application as filtering material. F \& S International Edition. Pall Filtersystems GmbH, Werk Schumacher,Zur Flügelau 70, 74564 Crailsheim / Germanypp. 22-24

[10] USAID (2008). Household water treatment options in developing countries: ceramic filtration. Centre for diseases control and prevention. United States Agency International Development. January 2008. http://www.wsp.org/filez/pubs/926200724252_eap_cambodia filter.pdf.

[11] CDC: Centre for Disease Control (2011). Household water treatment: Ceramic filtration. https://www.cdc.gov/safewater/pdf/ceramic_2011-final.pdf

[12] Jan B., Jan T., and Peter R. (2015). Prediction of mechanical properties - modulus of rupture and modulus of elasticity - of five tropical species by non-destructive methods. Maderas, Cienc. Tecnol. Vol. 17(2). Concepcion abr. 2015. Epub 25/02/2015. https://scielo.conicyt.cl/scielo.php?script $=$ sci_arttext $\&$ pid $=S O$ 718-221X2015000200003

[13] Hettiarachchi P., Motha, H.M. Pitawala T.G., (2011). Ceramica. Chilton Book Company Pennsylvania. pp. 285-290. [14] Cao Da-Li, Zhou Jing-Yi, Jin Yong-Ming, Ma Lei, Shi Zhong-Ning And Wang Zhao-Wen (2007). Effects of SiC and $\mathrm{MgO}$ on aluminabased ceramic foams filters. Research and Development Journal, China Foundry. Vol. 4, No. 4. November 2007.

[15] Ibeh M. I., (2019) Optimization of Ohiya Clay for Ceramic Applications Using Desirability Function Analysis, Ph.D 
dissertation, Department of Mechanical Engineering, Michael Okpara University of Agriculture, Umudike, Nigeria. 2019.

[16] Mcallister S. Analysis and comparison of sustainable water filters. EPD397 Microbiology 2005; 42(1), 159-167.

[17] World Health Organization (WHO). (2004). Meeting the MDG drinking water and sanitation target a mid-term assessment Progress, UNICEF AND WHO, Geneva.

www.scirj.org

(C) 2021, Scientific Research Journal

http://dx.doi.org/10.31364/SCIRJ/v9.110.2021.P1021894

This publication is licensed under Creative Commons Attribution CC BY. 